\title{
THE LINEAR RELATIONSHIP BETWEEN GROWTH TRAITS OF SHARPLANINA LAMBS IN EXTENSIVE FARMING PRACTICES
}

\author{
V. Caro Petrović ${ }^{1}$, M.P. Petrović ${ }^{1}$, M.M.Petrovic ${ }^{1}$, Z. Ilić ${ }^{2}$, J. Stojković , \\ D. Ružić Muslić ${ }^{1}$, N. Maksimovic ${ }^{1}$
}

1Institute for Animal Husbandry, Belgrade-Zemun

2Faculty for Agriculture, Lesak

Coressponding author: violycaro@yahoo.com

Original scientific paper

\begin{abstract}
The fastest phase of growth, observed in young animals, is often assumed to be linear, and linear regressions or ratios between BW gain and time are used to model growth. However, growth curves, due to their flexibility, are likely to be more suitable to describe even early growth. The research was performed in the region of Sharplanina Mountain in the population of the local Šarplanina breed of sheep. The following traits of lambs were considered: BWB, BW30, BW60 and BW90. Statistical analysis was conducted using the Pearson's correlation and multivariate linear regression model. This involved computing all possible and the best subset regression equation. Each equation was then assessed by its coefficient of determination (R2) and the constant based on the number of variable that used for the prediction. Results showed that weight of lambs from birth to weaning increased by about six times. Specifically lambs achieved an average total gain of $17.66 \mathrm{~kg}$, or $196 \mathrm{~g}$ per day. There were a very significant correlation $(\mathrm{P}<0.01)$ between $\mathrm{BWB}$ and $\mathrm{BW} 30, \mathrm{BW} 60$ and $\mathrm{BW} 90$. Likewise, shown a very significant correlation $(\mathrm{P}<0.01)$ between $\mathrm{BW} 30-\mathrm{BW} 60$, BW30BW90 and BW60-BW90. Also shown the coefficient of multiple determinations (R-squared R2) was 0.507 which means that $50.7 \%$ of the variance BW90, determined variance of the predictor variables represented in the model. Adjusted coefficient of multiple determination (adjusted R2) is 0.506 which means that $50.6 \%$ of the variance BW90, determined variance of the predictor variables that are in the model. Any increase in weight of lambs during the observed period of age is associated with an increase of dependent variable BW90. In particular, any increase in BW30 to $1 \mathrm{~kg}$, is associated with an increase in BW90 to $1.928 \mathrm{~kg}$.
\end{abstract}

Key words: lamb, growth, correlation, linear regression 


\section{Introduction}

Growth traits of lambs are of primary importance in the production of lamb meat. It is known as mentioned by Petrovic (2000) that there was correlation between growth traits. To define breeding program is necessary to know the strength of linear correlation among growth traits of lambs. The fit of a growth function, and hence the variables estimated, will depend on the number and timing of available BW observations. The fastest phase of growth, observed in young animals, is often assumed to be linear, and linear regressions or ratios between BW gain and time are used to model growth. However, growth curves, due to their flexibility, are likely to be more suitable to describe even early growth. The ability to change the shape of the growth curve by breeding may be an attractive prospect for livestock producers (e.g., to increase early growth but restrict mature size, and hence maintenance requirements). To determine the genetic flexibility of the shape of growth curves, genetic parameters must be calculated for the underlying curve variables (Lambe et al., 2006). The response to selection for a trait is dependent on the selection intensity, heritability, and linear relationship between growth traits (Snyman et al. 1997, Olivier et al. 2001). Genetic correlations among ewe traits were generally positive and moderate to high in magnitude. Also, selection on any of the component traits should not adversely affect other component traits, Bromley et al., (2001). Improvements in total weight of weaned lambs through selection on weaning weight and litter size at birth and weaning (Bradford et al., 1999; Olivier et al. (2001, Snowder, 2002, Cloete et al., 2004) have been reported. Riggio et al. (2008) estimated the genetic parameters of the body weight and suggested that taking live body weight of lambs into account as a selection criterion would increase selection accuracy. Such appropriate selective procedure requires accurate estimates of (co)variance components and genetic parameters. Genetic parameters for growth traits of different sheep breeds have been reported (Safari et al., 2005; Miraei-Ashtiani et al., 2007; Rashidi et al., 2008; Gowane et al., 2010; Mohammadi et al., 2010, Caro Petrović et al.,2012).The aim of this paper is to determine linear relationship and correlation between growth traits of lambs from Sharplanina breed of sheep.

\section{Material and methods}

The research was performed in the region of Sharplanina Mountain in the population of the local Sharplanina breed of sheep. All tested lambs had the same conditions of housing care and nutrition.

The following traits of lambs were considered: body weight at birth (BWB), body weight at 30 days (BW30), body weight at 60 days (BW60) body weight at 90 days (BW90). Animals were managed following traditional extensive 
farming practices. During spring-summer season, natural pasture was the main source of feed without any additives. During the autumn-winter season, the sheep were fed hay and concentrate. Lambing season was from January to March, and lambs were kept with their mothers while in the special box received high-quality hay and a concentrate with $18 \%$ of protein. Body weights of lambs were weighed at birth and once a month until weaning at 3 months of age. Statistical analysis was conducted using the software program SPSS (2012). Procedure was applied using the Pearson correlation and multivariate linear regressions model. This involved computing all possible and the best subset regression equation. Each equation was then assessed by its coefficient of determination (R2) and the constant based on the number of variable that used for the prediction.

Pearson coefficients of correlations are calculated using of the next formula:

Where:

$$
\mathrm{rxy}=\mathrm{Sxy} / \mathrm{Sx} \mathrm{x} \text { Sy }
$$

rxy $=$ Coefficient of correlations

Sxy $=$ Covariance

Sx and $\mathrm{Sy}=$ Standard deviations

Basic regressions model takes the form:

$\mathrm{Y}=\alpha+\beta 1 \mathrm{x} 1+\beta 2 \mathrm{x} 2+\ldots+\beta 1 \mathrm{x} 1+\beta \mathrm{nxn}$

where

$\mathrm{Y}=$ the expected value of the dependent variable

$\alpha=$ Value of the dependent variable when not yet begun to act independently variable

$\beta=$ the rate and direction of change of dependent variable in the value of independent variable

\section{Results and discussion} Table 1.

Results of means and standard errors for body weight of lambs are given in

From the said table, it can be observed that the weight of lambs from birth to weaning increased by about six times. Specifically lambs achieved an average total gain of $17.66 \mathrm{~kg}$, or $196 \mathrm{~g}$ per day. Compared with the results of other scholars (Petrović et al, 2011, Mekić et al, 2005), we can determine that the obtained values of growth alike with the other Pramenka sheep populations in the Balkan regions. 
Table 1. Body weight of lambs from birth to weaning, $\mathrm{kg}$

\begin{tabular}{|l|c|c|c|c|c|}
\hline Traits & $\mathrm{N}$ & Minimum & Maximum & Mean & S.E. \\
\hline BWB & 300 & 3.00 & 4.00 & 3.74 & \pm 0.01 \\
\hline BW30 & 300 & 8.50 & 12.00 & 9.92 & \pm 0.03 \\
\hline BW60 & 300 & 14.00 & 18.00 & 16.08 & \pm 0.06 \\
\hline BW90 & 300 & 19.10 & 25.00 & 21.40 & \pm 0.10 \\
\hline Valid N (listwise) & 300 & & & & \\
\hline
\end{tabular}

To persuade the strength of linear relationship or association, growth traits of lambs in Table 2, presented the values of Pearson correlation and covariance.

Covariance in probability theory and statistics is a measure of strength of the relationship between two variables. However, as an absolute measure of the degree of association is not suited for the assessment, and resort to the correlation coefficient as a relative measure, which in this paper done.

Table 2. Correlation and covariance of the growth traits of lambs from birth to weaning

\begin{tabular}{|c|c|c|c|c|c|}
\hline \multicolumn{2}{|l|}{ Traits } & BW1 & BW30 & BW60 & BW90 \\
\hline \multirow[t]{5}{*}{ BWB } & Pearson Correlation & 1 & $.560 * *$ & $.179 * *$ & $.359 * *$ \\
\hline & Sig. (2-tailed) & & .000 & .002 & .000 \\
\hline & $\begin{array}{l}\text { Sum of Squares and Cross- } \\
\text { products }\end{array}$ & 19.737 & 28.359 & 15.338 & 49.216 \\
\hline & Covariance & .066 & .095 & .051 & .165 \\
\hline & $\mathrm{N}$ & 300 & 300 & 300 & 300 \\
\hline \multirow[t]{5}{*}{ BW30 } & Pearson Correlation & $.560 * *$ & 1 & $.618^{* *}$ & $.712 * *$ \\
\hline & Sig. (2-tailed) & .000 & & .000 & .000 \\
\hline & $\begin{array}{l}\text { Sum of Squares and Cross- } \\
\text { products }\end{array}$ & 28.359 & 130.082 & 135.871 & 250.790 \\
\hline & Covariance & .095 & .435 & .454 & .839 \\
\hline & $\mathrm{N}$ & 300 & 300 & 300 & 300 \\
\hline \multirow[t]{5}{*}{ BW60 } & Pearson Correlation & $.179 * *$ & $.618^{* *}$ & 1 & $.466 * *$ \\
\hline & Sig. (2-tailed) & .002 & .000 & & .000 \\
\hline & $\begin{array}{l}\text { Sum of Squares and Cross- } \\
\text { products }\end{array}$ & 15.338 & 135.871 & 371.189 & 276.964 \\
\hline & Covariance & .051 & .454 & 1.241 & .926 \\
\hline & $\mathrm{N}$ & 300 & 300 & 300 & 300 \\
\hline \multirow[t]{5}{*}{ BW90 } & Pearson Correlation & $.359 * *$ & $.712 * *$ & $.466^{* *}$ & 1 \\
\hline & Sig. (2-tailed) & .000 & .000 & .000 & \\
\hline & $\begin{array}{l}\text { Sum of Squares and Cross- } \\
\text { products }\end{array}$ & 49.216 & 250.790 & 276.964 & 952.941 \\
\hline & Covariance & .165 & .839 & .926 & 3.187 \\
\hline & $\mathrm{N}$ & 300 & 300 & 300 & 300 \\
\hline
\end{tabular}


Based on the results of the above (table 2), have attained that there were a very significant correlation $(\mathrm{P}<0.01)$ between $\mathrm{BWB}$ and $\mathrm{BW} 30$, BW60 and BW90. Also, there were very significant correlation $(\mathrm{P}<0.01)$ between BW30-BW60, BW30-BW90 and BW60-BW90.

Correlation was highest between the weight of lambs at 30 days and body weight at 90 days $(0.712)$ and the lowest between body weight at birth and weight of lambs at 60 days $(0.179)$.

Correlation estimate of BW with other body weight traits was in agreement with estimate of Mohammadi et al., (2010) in Sanjabi sheep and Mohammadi et al. (2011) in Zandi sheep.

Positive correlations were reported by Duguma et al. (2002) in Tygerhoek Merino sheep, Gowane et al. (2010) in Malpura sheep. Correlation between BWB and BW90 in the present study (0.359) was consistent with the results of VaezTorshizi et al. (1992), Eftekhari-Shahroudi et al. (2002), Neser et al. (2001), and Baneh et al. (2010).

Positive correlations among body weight traits indicated that there was no genetic, phenotypic and environmental antagonist relationship among considered traits. selection for any of these body weights is likely to result in positive response in terms of genetic and phenotypic values.

Weight of lambs at 90 days from the aspect of research and practice is paramount, as it is the age of the market. To determine the size of the expected change of dependent variable $\mathrm{Y}$ (weight at 90 days- BW90) for each unit change in an independent variable $\mathrm{X}$ (BW60, BW30, BWB), performed a multivariate regression analysis, the results of which are presented in the Tables 3,4,5 and 6 .

Table 3. Regression model summary

\begin{tabular}{|l|c|c|c|c|}
\hline \multicolumn{5}{|c|}{ Model Summary } \\
\hline Model & R & R Square & Adjusted R Square & Std. Error of the Estimate \\
\hline 1 & $.712 \mathrm{a}$ & .507 & .506 & 1.25510 \\
\hline & & & & \\
\hline a. Predictors: (Constant), BW30
\end{tabular}

From the table 3, we can see that the method of "stepwise" had been formed models in one step, which shows that the coefficient of multiple regressions (R) is 0.712 . It is a measure of correlation between the score values of masses from 90 and a set of predictor variables that are in the final model.

It is also displayed that the coefficient of multiple determination (Rsquared R2) was 0.507 which means that $50.7 \%$ of the variance BW90, determined variance of the predictor variables represented in the model.

Adjusted coefficient of multiple determination (adjusted R2) is 0.506 which means that $50.6 \%$ of the variance BW90, determined variance of the predictor variables that were in the model. 
Regression as a model for predicting the physical development of lambs is used by many other researchers (Afolayan et al., 2006; Kunene et al., 2007; Hamito, 2009).

Results of analysis of variance are shown in table 4.

Table 4. Results of analysis of variance

\begin{tabular}{|l|l|c|c|c|c|c|}
\hline \multicolumn{7}{|c|}{ ANOVAa } \\
\hline Model & Sum of Squares & df & Mean Square & F & Sig. \\
\hline \multirow{3}{*}{1} & Regression & 483.506 & 1 & 483.506 & 306.933 & $.000 \mathrm{~b}$ \\
\cline { 2 - 7 } & Residual & 469.434 & 298 & 1.575 & & \\
\cline { 2 - 7 } & Total & 952.941 & 299 & & & \\
\hline \multicolumn{2}{|l|}{ a. Dependent Variable: BW90 } \\
\hline
\end{tabular}

From Table 4 have shown that the value of F-test is $306.933(\mathrm{P}=0.000)$, thus confirming that the multiple correlation coefficient in the final model statistically significant. In other words, the regression model significantly predicts the value of the criterion variables.

The final results of multiple or multiple regression are shown in Table 5.

Table 5. Results obtained regression coefficient

\begin{tabular}{|c|c|c|c|c|c|c|}
\hline \multicolumn{7}{|c|}{ Coefficients } \\
\hline \multirow{2}{*}{\multicolumn{2}{|c|}{ Model }} & \multicolumn{2}{|c|}{ Unstandardized Coefficients } & Standardized & \multirow[t]{2}{*}{$\mathrm{t}$} & \multirow[t]{2}{*}{ Sig. } \\
\hline & & B & Std. Error & Beta & & \\
\hline \multirow[t]{2}{*}{1} & (Constant) & 2.265 & 1.095 & & 2.068 & .039 \\
\hline & BW30 & 1.928 & .110 & .712 & 17.520 & .000 \\
\hline
\end{tabular}

From Table 5 can visualize that in the final model-1, in addition to the regression constants are also predictors BW30. Any increase in weight of lambs during the observed period of age is associated with an increase of the dependent variable BW90. In particular, any increase in BW30 to $1 \mathrm{~kg}$, is associated with an increase in BW90 to $1.928 \mathrm{~kg}$. Standardized coefficients in the table indicate the size of the standard deviation of changes in BW90 if the value of the predictor variables increased by one standard deviation. 
Based on the results of multiple regressions, it can be ceased that there is a significant linear correlation of medium intensity between the BW90 and body weight from birth to 60 days of observation.

The data show that about $50 \%$ of the variability of BW90, can be explained by variations BWB, BW30, BW60 and $50 \%$ of the variability is determined by other factors, particularly genetics and environment. Lewis and Brotherstone (2002) and Fischer et al. (2004), stated that regression method had a significant contribution in the prediction and assessment of growth of lambs. Some scholars (Bassano et al., 2001; Adeyinka and Mohammed, 2006; Thiruvenkadan, 2005; Kunene et al., 2007; Hamito, 2009) suggested that the number and particular type of traits required in a model depended on the breed, age of animals, season.

Table 6.Values of variables that are excluded from the model

\begin{tabular}{|c|c|c|c|c|c|c|}
\hline \multicolumn{7}{|c|}{ Excluded Variables } \\
\hline \multicolumn{2}{|l|}{ Model } & \multirow[t]{2}{*}{ Beta In } & \multirow[t]{2}{*}{$\mathrm{t}$} & \multirow[t]{2}{*}{ Sig. } & \multirow{2}{*}{$\begin{array}{c}\text { Partial } \\
\text { Correlation }\end{array}$} & $\begin{array}{c}\text { Collinearity } \\
\text { Statistics }\end{array}$ \\
\hline \multirow{3}{*}{1} & & & & & & Tolerance \\
\hline & BWB & $-.058 b$ & -1.182 & .238 & -.068 & .687 \\
\hline & BW60 & $.041 \mathrm{~b}$ & .789 & .430 & .046 & .618 \\
\hline \multicolumn{7}{|c|}{ a. Dependent Variable: BW90 } \\
\hline
\end{tabular}

Variables BWB and BW60 did not qualify for inclusion in the model because the condition $\mathrm{P}<0.05$ (Table 6).

From the table (6) can be seen that the value of Beta In, show how to make the coefficients of variables excluded if they were included in the model. Additionally, was also given the values and partial correlation coefficients. Based on the foregoing it can be affirmed that there is no significant linear relationship between BW90, BWB and BW60 (P> 0,05). This observation can be associated with the criteria in selection. Genetic parameters for growth traits of different sheep breeds have been reported (Safari et al., 2005; Miraei-Ashtiani et al., 2007; Rashidi et al., 2008; Gowane et al., 2010; Mohammadi et al., 2010, Caro Petrović et al.,2012).

\section{Conclusion}

Based on the research conducted and the results obtained, we can conclude that weight of lambs from birth to weaning increased by $17.66 \mathrm{~kg}$, or $196 \mathrm{~g}$ per day.

There were a very significant correlation between BWB and BW30, BW60 and BW90. Likewise, a very significant correlation obtained between BW30BW60, BW30-BW90 and BW60-BW90. 
The coefficient of multiple determinations means that $50.7 \%$ of the variance BW90, determined variance of the predictor variables represented in the model.

Adjusted coefficient of multiple determination means that $50.6 \%$ of the variance BW90, determined variance of the predictor variables that are in the model.

Any increase in weight of lambs during the observed period of age is associated with an increase of BW90 dependent variable. In particular, any increase in BW30 to $1 \mathrm{~kg}$, is associated with an increase in BW90 to $1,928 \mathrm{~kg}$.

\section{Linearna povezanost osobina porasta jagnjadi šarplaninske rase u ekstenzivnim uslovima gajenja}

V. Caro Petrović, M.P. Petrović, M.M Petrovic, Z. Ilic, J. Stojković, D.Ruzic Muslic, N. Maksimovic

\section{Rezime}

Istraživanje je sprovedeno $\mathrm{u}$ regionu Šar planine u populaciji lokalne šarplaninske rase ovaca. Sledeće osobine jagnjad su posmatrane: masa pri rođenju, sa 30,60 i 90 dana uzrasta (BWB, BW30, BW60 i BW90). Statistička analiza je sprovedena primenom SPSS paketa. Izračunate su Pearson korelacije i multivarijantna linearna regresija. To je značilo računanje svih mogućih i najboljih podskupova jednačina regresije. Svaka jednačina je ocenjena kao i njen koeficijent determinacije (R2). Rezultati su pokazali da je masa jagnjadi od rođenja do odbijanja povećana za oko šest puta. Konkretno jagnjad su ostvarila prosečan ukupan prirast od 17,66 kg, ili $196 \mathrm{~g}$ dnevno. Utvrđena je vrlo značajna korelacija (P <0,01) između BWB i BW30, BW60 i BW90. Isto tako, pokazala se veoma značajna korelacija $(\mathrm{P}<0,01)$ između BW30-BW60, BW30-BW90 i BW60-BW90. Takođe, dobijeni koeficijent višestruke determinacije (R-skuared R2) znači da je $50,7 \%$ varijanse BW90, determinisano varijansom prediktorskih varijabli predstavljenih u modelu. Korigovani koeficijent višestruke determinacije (R2 prilagođeni) je 0.506 , što znači da je $50,6 \%$ varijanse BW90, uslovljeno varijansama prediktorskih varijabli koje su u modelu. Svako povećanje mase jagnjadi u toku posmatranog perioda života je povezano sa povećanjem zavisno promenljive BW90. Praktično, svako povećanje BW30 za $1 \mathrm{~kg}$, je povezano sa povećanjem BW90 za $1.928 \mathrm{~kg}$. 


\section{References}

ADEYINKA I.A. AND MOHAMMED I.D. (2006): Relationship of live weight and linear body measurement in two breeds of goat of Northern Nigeria. Journal of Animal and Veterinary Advances, 5:891-893.

AFOLOYAN R.A., ADEYINKA I.A., LAKPINI C.A.M.( 2006): The estimation of live weight from body measurement in Yankasa sheep. Czech J. Anim. Sci. 51: 343-348.

BANEH H., HAFEZIAN S.H., RASHIDI A., GHOLIZADEH M. (2010): Estimation of genetic parameters of body weight traits in Ghezel sheep. AsianAust. J. Anim. Sci. 23: 149-153.

BASSANO B, BERGERO D., PERACINO A. (2001): Accuracy of body weight prediction in Alpine Ibex (Capra ibex, L. 1758) using morphometry. Journal of Animal Physiology and Animal Nutrition, 87: 79-85.

BRADFORD G.E. SAKUL H, DALLY M.R. (1999): Selection for weaning weight or litter size in range sheep. 11. Correlated responses and effect on productivity. Sheep Goat Res. Journal 15: 138-147.

BROMLEY C.M., VAN VLECK L.D., SNOWDER G.D. (2001): Genetic correlations for litter weight weaned with growth, prolificacy and wool traits in Columbia, Polypay, Ramboillet and Targhee sheep. Journal of Animal Science 79: 339-346.

CLOETE S.W.P., GILMOIR A.R., OLIVIER J.J., VAN WYK J.B. (2004): Genetic and Phenotypic trends and parameters in reproduction, greasy fleece weight and live weight in Merino lines divergently selected for multiple rearing ability. Aust. J. Exp. Agric. 44: 745-754.

DUGUMA G., SCHOEMAN S.J., CLOETE S.W.P., JORDAN G.F.(2002): Genetic parameter estimates of early growth traits in the Tygerhoek Merino flock. South African Journal of Animal Science 32, 66-75.

EFTEKHARI-SHAHROUDI E., BAHRINI M.R., VEN DOULK D., DANESH MESGARAN M. (2002):The factor affecting some economical traits in Kermani sheep. Iran. J. Agr. Sci. 33: 395-402.

FISHER T.M., VAN DER WERF J.H.F., BANKS R.G., BALL A.J. (2004): Description of lamb growth using random regression on field data. Livestock Production Science 89, 175-185.

GOWANE G.R., CHPRA A., PRAKASH V., ARORA A.L.(2010): Estimates of (co) variance components and genetic parameters for body weights and first greasy fleece weight in Malpura sheep. Livestock Science 131, 94-101.

HAMITO D. (2009): Estimation of weight and age of sheep and goats. Ethiopia sheep and goat productivity improvement program (ESGPIP). Technical Bulletin No. 23. P 11. 
KUNENE N., NESAMVUNI E.A., FOSSEY A.( 2007): Characterization of Zulu (Nguni) sheep using linear body measurements and some environmental factors affecting these measurements. S.Afr. J. Anim. Sci. 37 (1), 11-20.

KUNENE N., NESAMVUNI E.A., FOSSEY A.(2007): Characterization of Zulu (Nguni) sheep using linear body measurements and some environmental factors affecting these measurements. South African Journal of Animal Science. 37: 11-20. LAMBE N.R., NAVAJAS E.A., SIMM G., BUNGER L. (2006): A genetic investigation of various growth models to describe growth of lambs of two contrasting breeds. Journal of Animal Science vol. 84 no.10 pp 2642-2654.

LEWIS R.M. AND BROTHERSTONE S. (2002): A genetic evaluation of growth in sheep using random regression techniques. Animal Science 74, 60-70.

MEKIĆ C., PETROVIĆ M.P., TRIFUNOVIČ G.,ŽUJOVIĆ M., PERIŠIĆ D. (2005): Milk production of Svrljig stock of domestic tuff sheep. Biotechnology in Animal Husbandry 21 (5-6), p 85-88.

MIRAEI-ASTIANI S.R., SEYEDALIAN S.A.R., MORADI SHAHRBABAK M. (2007): Variance components and heritabilities for body weight traits in Sangsari sheep using univariate and multivariate animal models. Small Ruminant Research 73, 109-114

MOHAMMADI K., RASHIDI A., MOKHTARI M.S., BEIGI NASSIRI M.T. (2011): The estimation of (co)variance components for growth traits and Kleiber ratios in Zandi sheep. Small Ruminant 99, 116-121.

MOHAMMADI Y., RASHIDI A., MOKHTARI M.S., ESMAILIZADEH A.K.( 2010): Quantitative genetic analysis of growth traits and Kleiber ratios in Sanjabi sheep. Small Ruminant Research 93, 88-93

NESER F.W., ERASMUS G.J., VAN WYK J.B. (2001): Genetic parameter estimates for pre-weaning weight traits in Dorper sheep. Small Ruminant Res. 40: 197-202.

OLIVIER W.J., SNYMAN M.A., OLIVIER J.J., VAN WYK J.B., ERASMUS G.J.( 2001): Direct and correlated responses to selection for total weight of lamb weaned in Merino sheep. South African Journal of Animal Science 31: 115-121.

PETROVIĆ M.P. (2000): Genetika i oplemenjivanje ovaca. Beograd: Naučna knjiga.

PETROVIĆ V.C., PETROVIĆ M.P., PETROVIĆ M.M., ILIĆ Z.,MAKSIMOVIĆ N., RUŽIĆ-MUSLIĆ D., STOLIĆ N.(2012): Estimation of phenotypic and genetic trends of the growth traits in Lipska and Svrljig sheep. Biotechnology in Animal Husbandry 28 (4), p 743-749.

PETROVIČ M.P., RUŽIĆ-MUSLIĆ D., PETROVIĆ V.C., MAKSIMOVIĆ N. (2011): Influence of environmental factors on birth weight variability of indigenous Serbian breeds of sheep. African Journal of Biotechnology vol.10 (22), pp.46734676. 
RASHIDI A., MOKHTARI M.S., SAFI JAHANSHAHI A., MOHAMMAD ABADI M.R.( 2008): Genetic parameter estimates of pre-weaning growth traits in Kermani sheep. Small Ruminant Research 74, 165-171.

RIGGIO V., FINOCCHIARO R., BISHOP S.C.(2008): Genetic parameters for early lamb survival and growth in Scottish Blackface sheep. Journal of Animal Science 86, 1758-1764.

SAFARI E., FOGARTY, N.M., GILMOUR A.R. (2005): A review of genetic parameter estimates for wool, growth, meat and reproduction traits in sheep. Livestock Production Science 92, 271-289.

SAFARI, E., FOGARTY, N.M., GILMOUR, A.R. (2005): A review of genetic parameters estimates for wool, growth, meat and reproduction traits in sheep. Livestock Production Science 92, 271-289.

SNOWDER G.D.(2002): Composite trait selection for improving lamb production. Sheep and Goat Res. Journal 17: 42-49.

SNYMAN M.A., OLIVIER J.J., ERASMUS G.J., VAN WYK J.B.( 1997): Genetic parameter estimates for total weight of lamb weaned in Afrino and Merino sheep. Livest. Prod. Sci. 48, 111-116.

VAEZ TORSHIZI R., EMAM JOMEH N.,NIK KHAH A., HEJAZI M.(1992): A study of pre-weaning traits in a Baluchi sheep flock. Iranian Journal of Agricultural Science 23, 33-42. 